Article

\title{
Asexual Regeneration Response of Ilex canariensis Poir. to Management of the Canopy of Pinus radiata D.Don
}

\author{
José Ramón Arévalo \\ Department of Botany, Ecology and Plant Physiology, Faculty of Sciences, Universidad de La Laguna, \\ 38200 La Laguna, Tenerife, Spain; jarevalo@ull.edu.es
}

Received: 9 September 2020; Accepted: 26 October 2020; Published: 27 October 2020

\begin{abstract}
Exotic afforestation can provide suitable conditions for native shade-tolerant species restoration without threatening native forests. This study analyzes the impact of different thinning intensities of the canopy of an exotic Pinus radiata stand on the asexual regeneration response of Ilex canariensis, a native laurel forest species in the Canary Islands, Spain. The results provide useful indications for how to manage $P$. radiata stands to promote recovery of native plant communities. For different stand treatments were selected: stand clear cut, low intensity thinning (10-15\%), high intensity thinning (25\%), and a control. The stand clear cut management revealed Ilex canariensis individuals with a higher number of sprouts and more leaf cover; however, the height of these sprouts two years after the cut did not reach the values of individuals prior to this management. Consequently, the vitality index following clear cut management is significantly lower with respect to the other treatments. Thinning management is shown not to be so useful to promote the growth and vitality of Ilex canariensis individuals. The results suggest that thinning over $50 \%$ could be more appropriate in the case of Pinus radiata, allowing resprouting of Ilex canariensis in the understory and improvement in the vitality index.
\end{abstract}

Keywords: laurel forest; management; thinning; restoration

\section{Introduction}

Reintroduction of natural vegetation in areas reforested with exotic species and improvement in the plant community is considered restoration [1]. Afforestation with exotic species can have both negative and positive effects on the environment [2], such as increasing water demand and, on the other hand, protection from soil erosion. Exotic afforestation can also provide the right conditions for the establishment of native shade-tolerant species without threatening native forests, which have proven resilient to invasion by exotic species [3]. Indeed, several studies show that plantations of exotic species have facilitated forest succession in their understories at sites where disturbances have prevented recolonization by native forest species [4-6]. These are considered as facilitative or positive interactions in which encounters between organisms benefit at least one of the participants and cause harm to neither [7]. To generate management proposals for exotic plantations, the World Bank, the Institute for Tropical Forestry (USDA Forest Service), and the British Overseas Development Authority (ODA) initiated a global research network in 1994 to evaluate the role of such plantations in rehabilitating native forests [8].

Many of the afforestation plans for the Canary Islands, Spain, have been carried out with native species with the objective of restoring vegetation disturbed or removed during the previous five centuries following the European colonization of the islands [9]. However, some stands were reforested with the exotic species, Pinus radiata D.Don, instead of the endemic one, Pinus canariensis. 
In recent years, conservation managers have reconsidered the use of the plantations, moving away from the idea of using them solely as exploitable natural resources and toward managing them to restore the natural pine forest or the Macaronesian endemic laurel forest. The latter has been greatly disturbed and reduced to $10 \%$ of its potential area. Unfortunately, little information is available on pine forest dynamics, and the few quantitative studies there are deal specifically with fire effects [10-12]. Management of these exotic species and their eradication is one of the main aims of forest management programs of the Government of the Canary Islands, requiring ecological restoration studies to orientate this management.

The Macaronesian laurel forest is a subtropical forest, which is characteristic of some of the Macaronesian archipelagos (the Canary Islands, Madeira, and the Azores). Ilex canariensis (a native tree of the laurel forest) grows under the canopy, and its development and response to canopy treatments of Pinus radiata can be an indicator of the progress of laurel forest restoration. Under the canopy, I. canariensis regenerates mainly asexually by basal sprouts, but in open areas or forest borders, sexual regeneration is also common [13]. Forests cover roughly $25 \%$ of the Tenerife island land area and provide vital environmental services such as climate regulation, soil protection, and water management. Forest restoration should be implemented in order to increased or maintain this basic ecological process.

Therefore, the main objective of this study is to analyze the impact of different thinning intensities on the P. radiata stand on the asexual response of Ilex canariensis as a management indicator to promote the establishment of native plant communities. In this case, our hypotheses are first that Ilex canariensis increases its vitality, the more intense the thinning, and second, that basal sprouts and growth increase in relation to thinning intensity. An additional aim is to generate proposals to manage the forest following the approach of landscape silviculture and stand manipulation to avoid and/or recover the stand from natural or anthropogenic disturbances [14].

\section{Material and Methods}

\subsection{Study Site}

The study was carried out on the north east slope of the Corona Forestal Natural Park and Reserva Especial de las Palomas, in Tenerife $\left(28^{\circ} 19^{\prime} \mathrm{N}, 16^{\circ} 34^{\prime} \mathrm{W}\right)$, Canary Islands at approximately $1000 \mathrm{~m}$ a.s.l. (Figure 1). The park is c.a. 50,000 ha, and around 25\% of the park has been reforested with Pinus canariensis (except $2 \%$ in which Pinus radiata was planted). The bulk of the reforestation was conducted in 1930-1940 [15]. The sites selected for this study were planted in 1948-1952 (Figure 1). The study site and all the plots are located in similar areas with low environmental variability. Moreover, the characteristics of the stand presented low variation.

Potential natural vegetation is represented by laurel forest vegetation with dominant species such as Prunus lusitanica, Ilex perado, Ilex canariensis, Persea indica, Laurus novocanariensis, and Visnea mocanera (Lauro azoricae-Perseo indicae sigmetum association) [16]. The dominant shrub species differ between stands. A high number of annual and ruderal species is present at both sites, especially in the plots close to trails or those affected by other disturbances [17].

The annual precipitation of the park reaches $900 \mathrm{~mm}$ but can be twice this amount if fog drip is considered [18], with an irregular pattern, although rain is more common during winter. The mean annual temperature is around 15 degrees centigrade with minimal annual and daily fluctuations. Frost events may occur a few days a year at high altitudes. Soils at the study site have been classified in the order Entisol, suborder Orthens [19]. Nomenclature follows Acebes et al. 2004 [20]. 


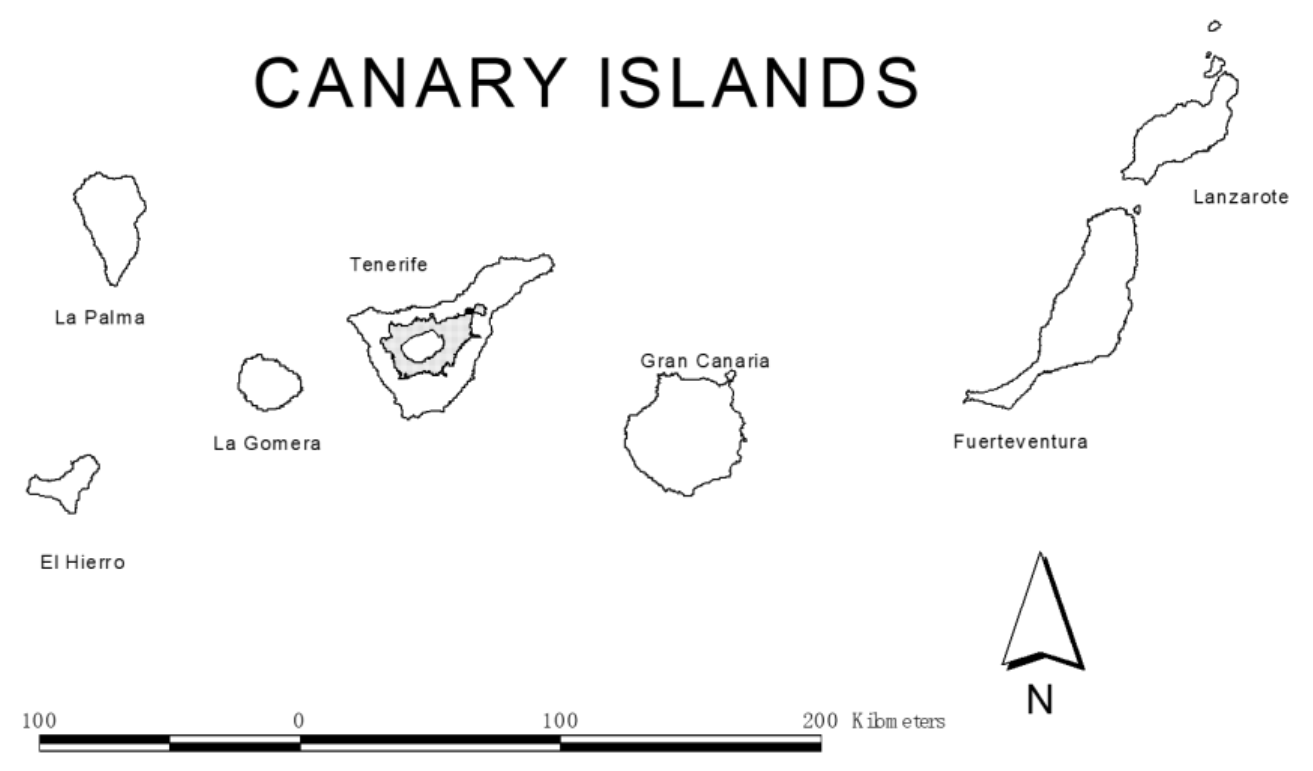

(a)

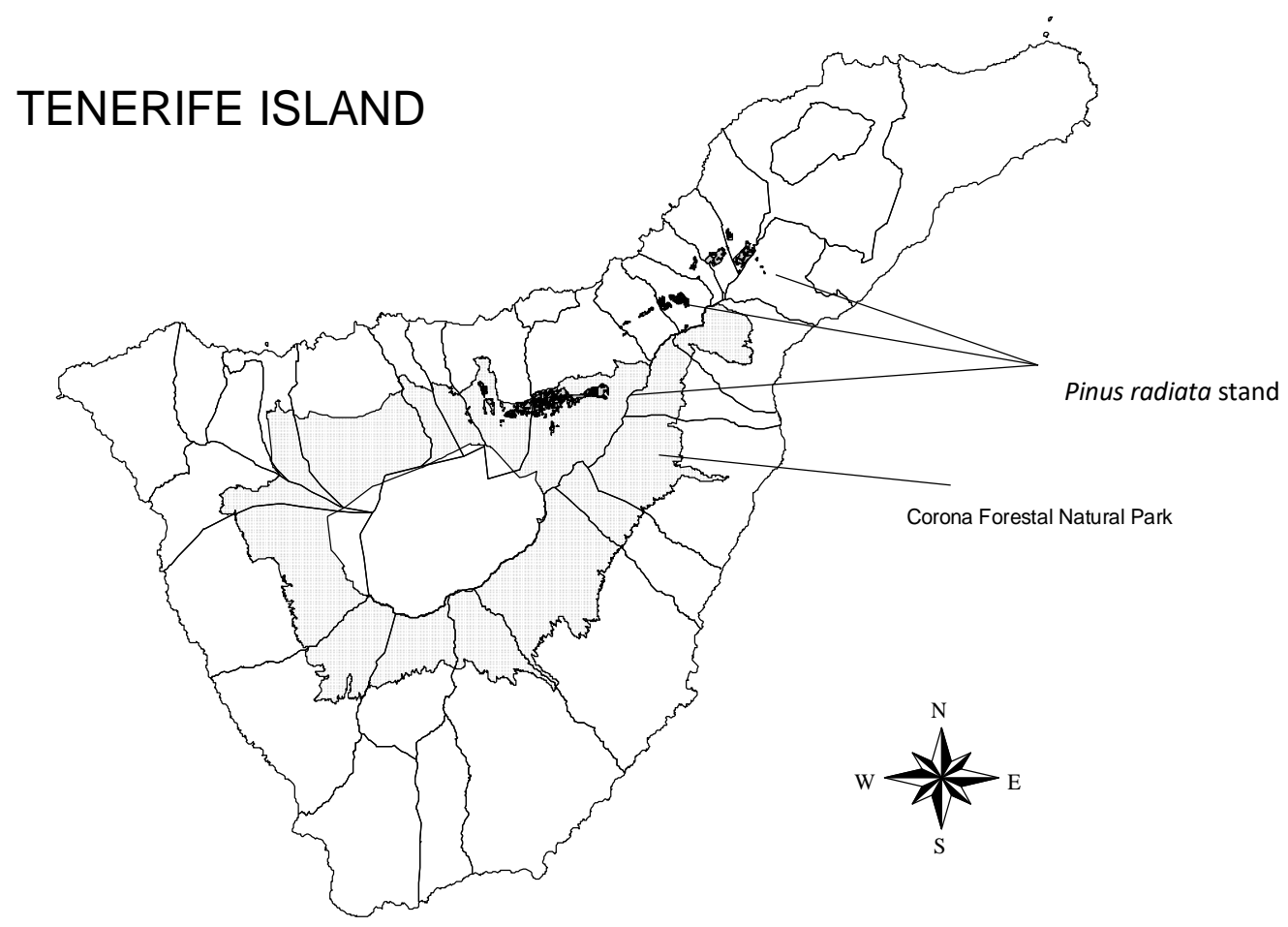

(b)

Figure 1. (a) Map of the Canary Islands, indicating Corona Forestal Natural Park in Tenerife island.

(b) Tenerife island: Darker marked areas of the park indicate the Pinus radiata stands.

\subsection{Design of the Experiment}

An area of 200 ha was managed for restoration in 2010. The density of Pinus radiata in this area was approximately of 700-800 ind/ha without any treatment [21], but some areas of the stands managed were reduced by $15 \%$ in density (hereafter " $\mathrm{LI}^{\prime}$ " for low intensity thinning) and another underwent more intense management with $25 \%$ reduction of density (hereafter " $\mathrm{HI}$ " for high intensity thinning). The planting of $P$. radiata was carried out 73 years ago. There were approximately 60 and 80 ha, 
respectively. Additionally, near this area, due to a major storm that took place a few months before management activities started, causing a high amount of damage to trees, all of these trees were removed over approximately 10 ha (hereafter "SC" for stand clear cut). Finally, there was an area without any treatment of management, which is considered the control (hereafter "CON"). The regeneration of $P$. radiata is very low in these plantations, and does not reveal invasive characteristics as for other species of Pinus.

Two points were randomly selected (separated approx. by $100 \mathrm{~m}$ ) in the middle of the different stand management categories (LI, HI, and CON) except for SC, where only one was chosen. After establishing the plot, I measured altitude, aspect, and slope, and estimated canopy cover of the stand using a convex spherical crown densitometer (measuring four points around the center point $A, B, C, D)$ [22]. At each point and using polar coordinates, information on the closest 20 individuals (or live coppice) of Ilex canariensis was used for measuring characteristics. All the plots were sampled two years after management.

For each individual, data on number of sprouts, measured mean height of the sprouts, maximum height, and estimated number of leaves were collected (using the following scale: class 1: 1-2 leaves, 2: $>1 \%$ of cover of all the branches, $3: 1-2 \%, 4: 2-5 \%, 5: 5-10 \%, 6: 10-25 \%, 7: 25-50 \%, 8: 50-75 \%$, 9: $>75 \%$ cover of the total). For all individuals, maximum height and two diameters (the larger one and its perpendicular from the canopy) from the top of the plant were measured, from which each individual's total biovolume was calculated, including all the sprouts. The biovolume multiplied by the leaf cover based on visual estimation was used as a vitality index.

\subsection{Statistical Analyses}

All of the different variables (number of sprouts, average height, maximum height, estimated cover of leaves, biovolume, and vitality index; considered the dependent variables) of the plots under different managements (HI, LI, SC, and CON; the independent factors) were compared individually using a two-way distance-based permutational repeated measures ANOVA, and the plots were applied as paired factors. Analysis was based on Bray-Curtis distances of raw data, with $p$-values obtained by using 9999 permutations of the appropriate exchangeable units [23]. Pairwise posteriori comparisons using $t$-statistics were applied when PERMANOVA revealed significant differences among groups (for $p<0.05$ ).

\section{Results}

The altitude of plots ranged between 960 and $1150 \mathrm{~m}$ a.s.l. and the canopy cover varied between 75 and $90 \%$, with the control plots presenting higher values, as expected. The other environmental variables also presented low variability (Table 1). Basal area and density before management remained at similar values in all the stands where the plots were located (with an average of $55-67 \mathrm{~m}^{2} / \mathrm{ha}$ and $700,800 \mathrm{ind} / \mathrm{ha}$ based on previous studies; [19]).

Table 1. Environmental characteristics of the different plots of the study.

\begin{tabular}{cccccccccc}
\hline Plot & Treatment & Slope $\left(^{\circ}\right)$ & Aspect & Altitude (m) & A & B & C & D & Avg. \\
\hline CON1 & Control & 25 & N & 1100 & 90 & 80 & 85 & 85 & 85 \\
CON2 & Control & 12 & NO & 1045 & 85 & 85 & 80 & 90 & 85 \\
LI1 & Low Intensity & 8 & N & 920 & 70 & 65 & 70 & 75 & 70 \\
LI2 & Low Intensity & 10 & N & 910 & 65 & 80 & 75 & 75 & 74 \\
HI1 & High Intensity & 10 & NO & 950 & 80 & 80 & 80 & 85 & 80 \\
HI2 & High Intensity & 10 & NO & 960 & 70 & 75 & 75 & 70 & 72 \\
SC & Stand Clear Cut & 10 & NO & 1090 & - & - & - & - & \\
\hline
\end{tabular}

The number of basal sprouts presented significant differences $\left(\right.$ PseudoF $_{6,13}=10.95, p<0.001$ ), but pairwise analysis revealed that only the SC plot differed from the rest, with average values over five 
sprouts (Figure 2a). The estimated number of leaves also presented significant differences, with higher values in the SC plots and non-regular patterns among the others $\left(\right.$ PseudoF $_{6,13}=39.11, p<0.001$; Figure $2 b)$. The average height of the sprouts revealed significant differences with higher values for $\mathrm{HI}$ and LI with respect to SC and CON (PseudoF $6,13=18.13, p<0.001$; Figure 2c). In the case of maximum sprout height, higher significant values were presented in $\mathrm{HI}$ and $\mathrm{LI}\left(\mathrm{PseudoF}_{6,13}=9.68, p<0.001\right.$; Figure 2d).

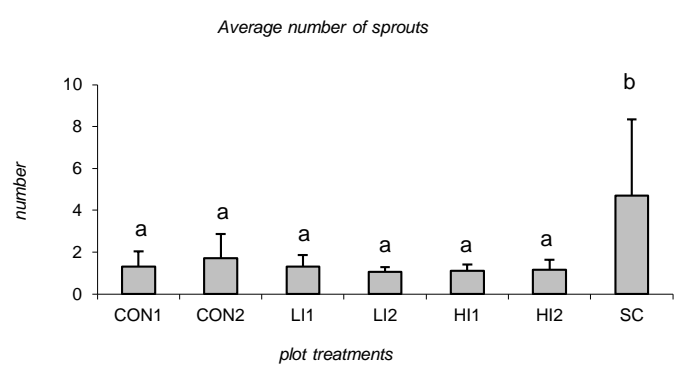

c)

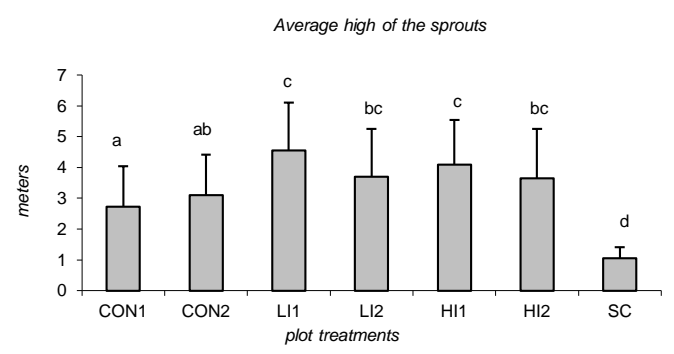

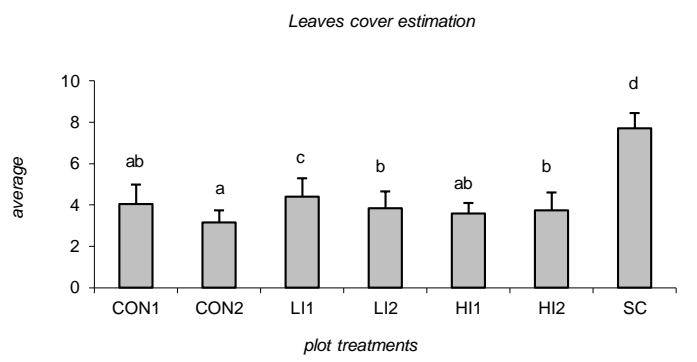

d)

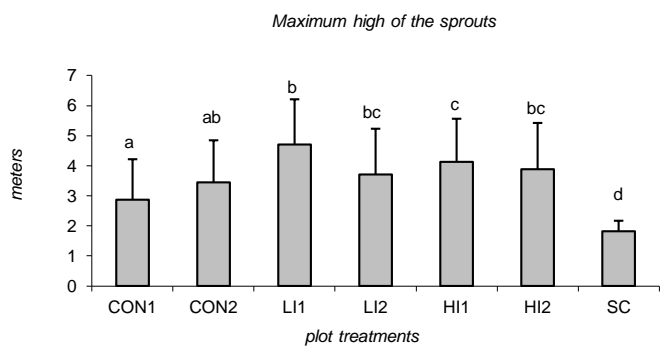

Figure 2. Mean values and standard deviations of the 20 individuals in each plot. (a) Average number of sprouts (meters); (b) leaf cover estimation; (c) average height of sprouts (meters); (d) maximum height of sprouts (meters). Identical letters above the bars indicate non-significant differences.

For biovolume and the vitality index, the results followed a similar pattern, with higher values of biovolume and index for $\mathrm{HI}$ and LI treatments $\left(\right.$ PseudoF $_{6,13}=13.50, p<0.001$ and PseudoF $_{6,13}=5.98$, $p<0.001$, respectively; Figure 3a,b).

a)

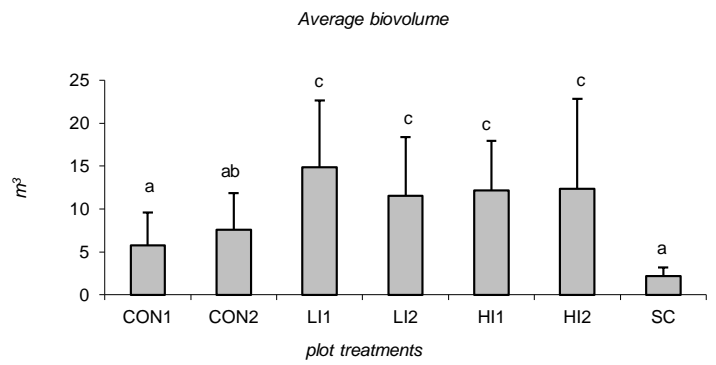

b)

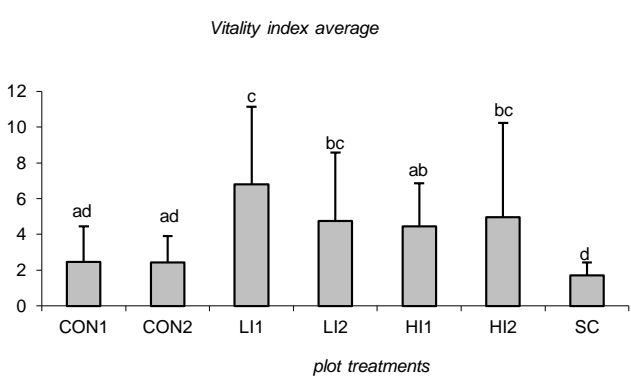

Figure 3. Mean values and standard deviations of the 20 individuals in each plot (a) Average biovolume of the individuals $\left(\mathrm{m}^{3}\right)$; $(\mathbf{b})$ vitality index average. Identical letters above the bars indicate non-significant differences.

\section{Discussion}

The main objective of this study is to develop the best management practices to promote and restore the native plant community based on the response to treatments of a Pinus radiata canopy of one of the dominant native species, Ilex canariensis. As the exotic canopy has produced a nursery effect, it is considered an important driving force of plant community succession and/or vegetation restoration [24] and facilitates the recovery of native vegetation [8]. However, native species 
development after 60-70 years has been interrupted by the presence of the canopy of other exotic species. Using Ilex canariensis as an indicator of the recovery of the understory, the most appropriate management can be selected. Asexual regeneration increases the occupancy rate of the spaces produced by the forest management and could help to restore part of the $90 \%$ of the laurel forest that has been lost over the last 500 years [25].

The SC management revealed that the measured individuals presented a larger number of sprouts and more leaf cover. However, the height of these sprouts 2 years after the cut did not reached the values of the individuals prior to this management. Consequently, the vitality index is significantly lower with respect to the other treatments, except for the control plot (Figures 2 and 3).

Although the CON management presents lower values of sprouts and height of the sprouts, these were non-significant with respect to the values of LI and HI. Thus, the thinning management has not been very useful in promoting the regeneration of species growing in the understory, or as a regenerative tool of the canopy. In the case of other studies on the native pine in the Canary Islands, Pinus canariensis $[24,26]$, in order to produce significant results through thinning, canopy openness should be much greater than that provided by the management practices ( 25 and $50 \%$ of density), requiring at least $>50 \%$ open canopy for a few years to favor establishment (it should be ensured that trees around the gaps are unable to close the canopy with their branches). This fact is supported by the low differences that CON, HI, and LI present with respect to canopy cover, because of the fast closing of the canopy with branches of surrounding individuals.

In this case, we can speculate that thinning over $50 \%$ could be more appropriate in the case of Pinus radiata, allowing resprouting of Ilex canariensis in the understory, and also the improvement of the vitality index. This technique cannot be extrapolated in the case of Pinus canariensis, as this species is able to resprout and will reach the canopy faster than other species of the understory.

The laurel forest of the Canary Islands is the most emblematic vegetation type of the Canary Island archipelago. Thus, restoration programs are being developed to increase laurel forest area on islands such as Tenerife. Today, less than $10 \%$ of the original laurel forest on Tenerife remains at a good conservation level [27].

\section{Conclusions}

Based on these results, I can suggest the maintenance of the Pinus radiata stand in the present conditions in the studied area. This nursery effect of the canopy of $P$. radiata can be seen at different levels (increases in soil humidity, organic matter, provision of benign habitats, or more favorable conditions for germination [28-30]), but management will be necessary in order to enhance the recovery of the natural laurel forest, as is revealed in the studied Ilex canariensis as an indicator species and the low development of leaves or poor growth after management. Canopy opening over the levels analyzed in this study will be required in order to succeed in reverting an exotic canopy to the natural laurel forest.

These findings and their implications should be discussed in the broadest context possible. Future research directions should be aimed at promoting increased regeneration of the laurel forest.

Funding: This study was funded by the Cabildo Insular de Tenerife.

Acknowledgments: Thanks to the "Cabildo Insular de Tenerife" and its "Sección de Biodiversidad" for the support and permits to carry out this study.

Conflicts of Interest: The author declares no conflict of interest.

\section{References}

1. Palmer, M.A.; Zedler, J.B.; Falk, D.A. Foundations of Restoration Ecology; Island Press: Washington, DC, USA, 2016.

2. Arévalo, J.R.; Delgado, J.D.; Fernández-Palacios, J.M. Regeneration of potential laurel forest under a native canopy and an exotic canopy, Tenerife (Canary Islands). For. Syst. 2011, 20, 255-265. [CrossRef] 
3. Geldenhuys, C.J. The Blakwood Group system, its relevance for sustainable forest management in the southern Cape. S. Afr. For. J. 1996, 178, 15-24.

4. Parrotta, J.A. Influence of overstory composition on understory colonization by native species in plantations on a degraded tropical site. J. Veg. Sci. 1995, 6, 627-636. [CrossRef]

5. Fimbel, A.R.; Fimbel, C.C. The role of exotic conifer plantations in rehabilitating degraded tropical forest lands, i.c. A case study from the Kivale Forest in Uganda. For. Ecol. Manag. 1996, 81, 215-226. [CrossRef]

6. Loumeto, J.J.; Huttel, C. Understory vegetation in fast growing tree plantations on savanna soils in Congo. For. Ecol. Manag. 1997, 99, 65-81. [CrossRef]

7. Bruno, J.F.; Stachowicz, J.J.; Bertness, M.D. Inclusion of facilitation into ecological theory. Trends Ecol. Evol. 2003, 18, 119-125. [CrossRef]

8. Parrotta, J.A.; Turnbull, J.W.; Jones, N. Catalyzing native forest regeneration on degraded tropical lands. For. Ecol. Manag. 1997, 99, 1-7. [CrossRef]

9. De Nascimento, L.; Willis, K.J.; Fernández-Palacios, J.M.; Criado, C.; Whittaker, R.J. The long-term ecology of the lost forests of La Laguna, Tenerife (Canary Islands). J. Biogeogr. 2009, 36, 499-514. [CrossRef]

10. Höllermann, P. The impact of fire in Canarian ecosystems 1983-1998. Erdkunde 2000, 54, 70-75. [CrossRef]

11. Arévalo, J.R.; Fernández-Palacios, J.M.; Jiménez, M.J.; Gil, P. The effect of fire intensity on the understory species composition of two Pinus canariensis reforested stands in Tenerife (Canary Islands). For. Ecol. Manag. 2001, 148, 21-29. [CrossRef]

12. Arévalo, J.R.; Naranjo-Cigala, A. Wildfire impact and the FIRE PARADOX in a natural and endemic pine forest stand and shrubland. Fire 2018, 1, 44. [CrossRef]

13. Fernández-Palacios, J.M.; Arévalo, J.R.; González-Delgado, G.; Delgado, J.D.; Otto, R. Estrategias de regeneración en la laurisilva. Makaronesia 2004, 6, 90-101.

14. Pretzsch, H. Forest Dynamics, Growth, and Yield; Springer: Berlin/Heidelberg, Germany, 2009.

15. Del Arco, M.J.; Wildpret, W.; Pérez de Paz, P.L.; Rodríguez-Delgado, O.; Acebes, J.R.; García-Gallo, A.; Martín, V.E.; Reyes-Betancort, J.A.; Salas, M.; Bermejo, J.A.; et al. Mapa de Vegetación de Canarias; GRAFCAN: Santa Cruz de Tenerife, Spain, 2006.

16. Del Arco, M.J.; Pérez de Paz, P.L.; Salas, M.; Wildpret, W. Atlas Cartográfico de los Pinares Canaries: II Tenerife; Viceconsejería de Medio Ambiente: Santa Cruz de Tenerife, Spain, 1992.

17. Ceballos, L.; Ortuño, F. Vegetación y Flora Forestal de las Islas Occidentales, 2nd ed.; Cabildo Insular de Tenerife: S/C de Tenerife, Spain, 1974.

18. Kämmer, F. Klima und Vegetation auf Tenerife, besonders in Hinblick auf den Nebelniederschlag. Scripta Geobot. 1974, 7, 1-78.

19. Fernández-Caldas, E.; Tejedor, M.; Quantin, P. Los Suelos Volcánicos de Canarias; Servicio de Publicaciones de La Universidad de La Laguna: La Laguna, Spain, 1985.

20. Acebes, J.R.; del Arco, M.; García, A.; León, M.C.; Pérez de Paz, P.L.; Rodríguez, O.; Wildpret, W.; Martín, V.E.; Marrero, M.C.; Rodríguez, L. Pteridophyta, Spermatophyta. In Lista de Especies Silvestres de Canarias (Hongos, Plantas y Animales Terrestres); Izquierdo, I., Martín, J.L., Zurita, N., Arechavaleta, M., Eds.; Consejería de Medio Ambiente y Ordenación Territorial, Gobierno de Canarias: S/C de Tenerife, Spain, 2004; pp. 96-143.

21. Arévalo, J.R.; García, G.; Montes de Oca, Y.; Fernández, S. Differences in Carbon Sequestration in Native vs. Exotic Pine Species (Tenerife, Canary Islands). Bull. UASVM Ser. Agric. 2013, 70, 299-303.

22. Lemmon, P.E. A new instrument for measuring forest overstory density. J. For. 1957, 55, 667-668.

23. Anderson, M.; Gorley, R.N.; Clarke, R.K. Permanova + for Primer: Guide to Software and Statistical Methods; PRIMER-E: Plymouth, UK, 2008.

24. Ren, H.; Long, Y.; Nan, L. Nurse plant theory and its application in ecological restoration in lower subtropics of China. Prog. Nat. Sci. 2008, 18, 137-142. [CrossRef]

25. Fernández-Palacios, J.M.; Arévalo, J.R.; Balguerías, E.; Barone, R.; De Nascimento, L.; Elias, R.B.; Delgado, J.D.; Fernández-Lugo, S.; Méndez, J.; Menezes de Sequeira, M.; et al. La Laurisilva. Canarias, Madeira y Azores; Editorial Macaronesia: SC de Tenerife, Spain, 2017.

26. Arévalo, J.R.; Fernández-Palacios, J.M. Natural regeneration of Pinus canariensis Chr. Sm. ex DC in Buch in forest plantations after thinning. Open For. Sci. J. 2008, 1, 54-60. [CrossRef]

27. Santos, A. Bosques de Laurisilva en la Región Macaronésica; Colección Naturaleza y Medio ambiente, 49; Council of Europe: Strasbourg, France, 1990. 
28. Onaindia, M.; Mitxelena, A. Potential use of pine plantations to restore native forests in a highly fragmented river basin. Ann. For. Sci. 2009, 66, 1-11. [CrossRef]

29. Adam, F.S.; Norton, D.A.; Carswell, F.E. Artificial canopy gaps accelerate restoration within an exotic Pinus radiata plantation. Restor. Ecol. 2016, 24, 336-345.

30. Lameira, L.L.; Ferreira, F.C.; Esteves, R.A.; Queiroz, J. Plant-canopy Effects on Natural Regeneration in Sites Under Restoration: Do Tree Species Matter? Floresta Ambiente 2019, 26. [CrossRef]

Publisher's Note: MDPI stays neutral with regard to jurisdictional claims in published maps and institutional affiliations.

(C) 2020 by the author. Licensee MDPI, Basel, Switzerland. This article is an open access article distributed under the terms and conditions of the Creative Commons Attribution (CC BY) license (http://creativecommons.org/licenses/by/4.0/). 